\title{
AXL Overexpression Positive
}

National Cancer Institute

\section{Source}

National Cancer Institute. AXL Overexpression Positive. NCI Thesaurus. Code C148406.

An indication that overexpression of $\mathrm{AXL}$ has been detected in a sample. 